\title{
Agro-Meteorological Monitoring: A Study Based on Observations from Akure, Ondo State, Nigeria
}

\author{
F.O Abulude ${ }^{1, *}$, S.D Fagbayide ${ }^{2}$ and A.S Efunboade ${ }^{3}$ \\ ${ }^{1}$ Science and Education Development Institute, Akure, Ondo State, Nigeria \\ ${ }^{2}$ Department of Agricultural and Bio-Environmental Engineering, The Federal Polytechnic, Ilaro, \\ Ogun State, Nigeria; fsamueldare@gmail.com \\ ${ }^{3}$ Federal College of Agriculture, Akure, Ondo State, Nigeria; asefunbohade@yahoo.com \\ *Corresponding author: samuel.fagbayide@federalpolyilaro.edu.ng
}

\begin{abstract}
Agro-meteorology is the relationship between agriculture and weather. All farm activities are affected by weather. Therefore it is always necessary to monitor the weather as a forecast. The aim of the research was to monitor the weather and rainwater samples obtained at Federal College of Agriculture, Akure, Ondo State, Nigeria. For the eight months periods, results were obtained. The mean results for the physicochemical parameters were: TDS $(12.25 \mathrm{mg} / \mathrm{L})$, temp $\left(28.13{ }^{\circ} \mathrm{C}\right), \mathrm{pH}(6.63), \mathrm{EC}(24.25 \mu \mathrm{S} / \mathrm{cm})$, Free $\mathrm{CO}_{2}(24.38 \mathrm{mg} / \mathrm{L})$, nitrate $(0.16 \mathrm{mg} / \mathrm{L})$, phosphate $(0.17 \mathrm{mg} / \mathrm{L})$, sulphate $(0.18 \mathrm{mg} / \mathrm{L})$. The rainwater was colorless and had no odor. The mean meteorological data: The prevailing wind directions were from SE, mostly in May, June, July and November and NE. The dry and wet temperatures were $22-29{ }^{\circ} \mathrm{C}$ and $20-26{ }^{\circ} \mathrm{C}$ respectively. The maximum value was observed in the month of July. The correlation matrix showed that there were many strong correlations in the physicochemical properties. The months of May, June and July had the highest wind speed. In these months there would be a need to use a windbreaker around the crops planted to avoid soil erosion and damaging of plants.
\end{abstract}

KEYWORDS: rainwater; weather; windbreaker; cup anemometer; dry and wet bulb thermometers

\section{INTRODUCTION}

Agro-meteorology is the relationship between agriculture and weather. All farm activities are affected by weather. Few applications of weather to agriculture are Crop management, planning for stability in production, monitoring, protection of crops to harsh, soil formation, livestock production just to mention a few (Agroinfo, 2015). Poultry and livestock productions also depend on weather and meteorology provides the information for successful livestock production and husbandry. To account for the impact of weather and climate variability on crop production, agro-meteorological variables are one of the key inputs required for the operation of crop 
simulation models. These include maximum and minimum air temperature, total solar radiation, wind direction and speed, relative humidity, precipitation and rainfall (Hoogenboom, 2000).

Rainfall plays a major role in determining agricultural production and hence the economic and social well-being of rural communities. The rainfall pattern in sub-Saharan Africa is influenced by large-scale intra-seasonal and inter-annual climate variability (Haile, 2005).

Water serves many functions in food sustainability. Different forms of water have different uses in farming activities. Rainwater and other surface and ground water are useful for livestock, fisheries and crop production. Farm pond water needs to be observed for the presence of algae and other harmful organisms during hot, dry weather (Donald et al., 2001).

In this study, rainwater was harvested for a period of eight months, while the temperature, wind speed, and direction were monitored. The essence of this was to establish the relationship between the meteorological parameters and physicochemical characteristics of rainwater within the same environment. Therefore, the aim of the research was to monitor the weather and rainwater samples obtained at Federal College of Agriculture, Akure, Ondo State, Nigeria.

\section{MATERIALS AND METHODS}

\section{Sampling Area}

The rainwater samples and meteorological (wind direction and speed and dry and wet thermometer) data were collected at the REC campus of Federal College of Agriculture, Akure, Ondo State, Nigeria. Samples were collected for a period of eight (8) months (May to December 2015).

\section{Sample Collection}

Rainwater sample was collected once a month, using the sampler shown in Fig 2. A simple system made with a high-density polyethylene (HDPE) bottle (5L) connected to a HDPE funnel. The container was placed on sampling stand at a height above $1.5 \mathrm{~m}$ ground in order to prevent lichen-forming during the sampling period. After a month the rainwater sample collected was filtered using Whatman ashless filter paper $(11.0 \mathrm{~cm}$, Cat. No. 14442110$)$.

The physicochemical parameters $\left(\mathrm{pH}, \mathrm{TDS}, \mathrm{EC}\right.$, free $\mathrm{CO}_{2}$, Colour, odor, temperature, nitrate, sulphate, and phosphate) of the rainwater were subjected to appropriate determinations using standard methods of analyses. 


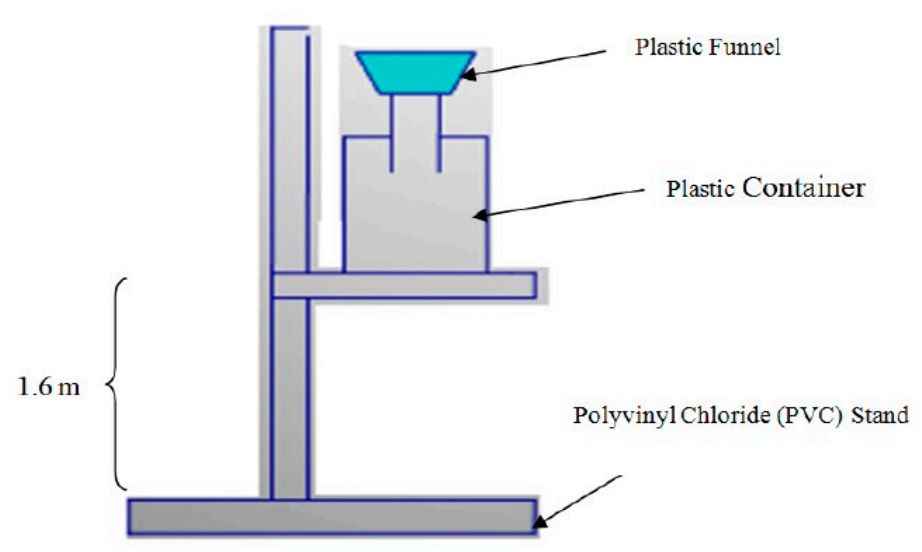

Fig 3: Diagram of locally assembled TAD gauge

\section{Statistical Analysis}

Data obtained (The basic descriptions, correlation coefficient, cluster analysis, and PCA) were generated in triplicates and analyzed using Minitab 16 Statistical Software.

\section{RESULTS AND DISCUSSION}

Table 1 shows the basic descriptions of the physicochemical parameters. The results showed that the $\mathrm{pH}$ of the rainwater samples varied between 6.10 and 7.60. It shows not too acidic and alkaline. This means the rainwater within these periods will be suitable for the growth of crops, serve as drinking water for poultry and livestock animals, and other uses it might be subjected to. A low $\mathrm{pH}$ value of water can be unpalatable, corrosive to equipment, and may have a harmful impact on performance. A high $\mathrm{pH}$ in water is not good since it reflects high levels of calcium and magnesium, which can clog watering systems (Fig 2). According to Kentucky Poultry Energy Efficiency Project (2014), livestock animals and poultry birds accept water on the acid side better than they accept on the alkaline side. TDS ranged between 4 and $42 \mathrm{mg} / \mathrm{L}$. High values of TDS were recorded in the months of November $(19 \mathrm{mg} / \mathrm{L})$ and December $(42 \mathrm{mg} / \mathrm{L})$. The results obtained in this study were not in agreement with values $(236,232,242$, and $755 \mathrm{mg} / \mathrm{L}$ ) obtained by Elsaidy et al., (2015). It is gratifying to note that the results were far below the recommended values (0-1000) for Poultry water quality standards (Elsaidy et al., (2015). The rainwater samples for the eight months period were colorless and the odor (objectionable). Color can be impacted in water samples by the presence of particles such as clay, silt, or organic material. This may have an effect on the proper functioning of watering equipment and can have adverse effects on flock performance. A foul odor in water is an indication of hydrogen sulfide in water. The taste of water can be affected by the presence of different salts. A bitter taste, for example, is associated with the presence of ferrous and manganese sulfates. EC (electrical conductivity) ranged between 8 and $84 \mu \mathrm{S} / \mathrm{cm}$. EC is an important factor when deciding on water for irrigation. If a salt-sensitive crop is to be grown, 
efforts should be geared up to make use of water with a conductivity less than $700 \mu \mathrm{S} / \mathrm{cm}$. A high conductivity water $(5000 \mu \mathrm{S} / \mathrm{cm})$ will be good for salt tolerant crops. The rainwater sample collected will be suitable for general purpose in agriculture. Free $\mathrm{CO}_{2}$ in the rainwater samples are low (16 -32mg/L). According to Carles et al., (2015), warmer temperatures and $\mathrm{CO}_{2}$ elevation had a positive effect on the height and diameter growth of 2- and 3-year-old seedlings full-sib families. As low as this content in the water sample, crops planted with it will have a positive effect on their photosynthesis and eventually growth.

The ions in the rainwater samples are: nitrate $(0.05-0.83 \mathrm{mg} / \mathrm{L})$, phosphate $(0.13-0.19 \mathrm{mg} / \mathrm{L})$ and sulphate $(0.15-0.24 \mathrm{mg} / \mathrm{L})$. CV (\%) are 176.25, 11.22 and 17.19, Skewness: $2.81,0.81$ and 0.88 , Kurtosis: $7.92,0.92$ and 0.04 respectively. The study produced low values of nitrate and sulphate and compared to rainwater (nitrate, $31.9-39 \mathrm{mg} / 1$, and sulphate value between 11 $14 \mathrm{mg} / \mathrm{l}$ ) obtained from different roofs in Ogbomoso, Nigeria. Our results of nitrate, sulphate and phosphate were comparable to those obtained for another rainwater from Warri, Delta State, Nigeria (Olowoyo, 2011).

Correlation matrix of the physico-chemical parameters like TDS and Temp $\left(r^{2}=0.710\right)$, TDS and $\mathrm{pH}\left(\mathrm{r}^{2}=0.648\right)$, TDS and EC $\left(\mathrm{r}^{2}=0.998\right)$, Temp and $\mathrm{pH}\left(\mathrm{r}^{2}=0.900\right)$, Temp and $\mathrm{EC}\left(\mathrm{r}^{2}=0.716\right), \mathrm{pH}$ and EC $\left(r^{2}=0.660\right)$, TDS and Phosphate $\left(r^{2}=0.621\right)$, TDS and Sulphate $\left(r^{2}=0.854\right)$, Temp and phosphate $\left(\mathrm{r}^{2}=0.721\right)$, Temp and sulphate $\left(\mathrm{r}^{2}=0.892\right), \mathrm{pH}$ and phosphate $(\mathrm{r} 2=0.702), \mathrm{pH}$ and sulphate $\left(r^{2}=0.775\right)$, EC and phosphate $\left(r^{2}=0.658\right)$ and EC and sulphate $\left(r^{2}=0.870\right)$ were strongly correlated (Table 2). The correlation figures are depicted bold. The relationship could be due to a common source or chemical similarity.

Figs. 3(a) and 3(b) showed the monthly assessment of meteorological parameters such as wind speed (line graph), wind direction (wind rose), dry and wet temperature (line graph), at the meteorological station during the eight-month study. The prevailing wind directions were from SE, mostly in May, June, July and November and NE. The dry and wet temperatures were 22$29^{\circ} \mathrm{C}$ and $20-26^{\circ} \mathrm{C}$. The maximum value was observed in the month of July. It was observed that the temperature in between the prevailing winds was similar. Wind direction and speed has beneficial and harmful effects on crops. They increase transpiration and turbulence in the atmosphere, photosynthesis, and alters the balance of hormones. In the case of harmful effects, shoots are damaged, flower and fruits are shed, roots are uprooted, soil erosion and lodging. To reduce the effect across a prevailing wind, it is suggested that windbreaks should be used, supports should be used and direction of planting should be adjusted (TNAU Agritech Portal, accessed 2016). Onoda and Anten (2011) confirmed that wind is one of the environmental stress that affects plant development, reproduction, and growth. 


\begin{tabular}{|c|c|c|c|c|c|c|c|}
\hline $\begin{array}{c}\text { Contamination or } \\
\text { characteristic }\end{array}$ & $\begin{array}{l}\text { Level } \\
\text { considered } \\
\text { average }\end{array}$ & $\begin{array}{l}\text { Maximum } \\
\text { acceptable } \\
\text { level }\end{array}$ & Remarks & & & & \\
\hline Bacteria & & & & Iron & $0.2 \mathrm{mg} / \mathrm{l}$ & $0.3 \mathrm{mg} / \mathrm{l}$ & $\begin{array}{l}\text { Higher levels produce } \\
\text { a bad odor and taste }\end{array}$ \\
\hline Total bacteria & $0 / \mathrm{ml}$ & $100 / \mathrm{ml}$ & \multirow{2}{*}{$0 / \mathrm{ml}$ is desirable } & Lead & - & $0.2 \mathrm{mg} / 1$ & Higher levels are toxic \\
\hline Coliform bacteria & $0 / \mathrm{ml}$ & $50 / \mathrm{ml}$ & & \multirow{5}{*}{ Magnesium } & \multirow{5}{*}{$14 \mathrm{mg} /$} & \multirow{5}{*}{$125 \mathrm{mg} / \mathrm{l}$} & Higher levels have a \\
\hline & Nitrogen & compounds & & & & & laxative effect. Levels \\
\hline Nitrate & $10 \mathrm{mg} / \mathrm{l}$ & 25 to $45 \mathrm{mg} !$ & $\begin{array}{c}\text { Levels from } 3 \text { to } 20 \\
\text { mo/l affect }\end{array}$ & & & & \\
\hline Nitrite & $0.4 \mathrm{mg} / \mathrm{l}$ & $4 \mathrm{mg} / \mathrm{l}$ & performance & & & & \\
\hline & & & & & & & high. \\
\hline pH & 6.8 to 7.5 & - & $\begin{array}{l}\text { A pH of less than } 6.0 \text { is } \\
\text { not desirable. Levels } \\
\text { below } 6.3 \text { may } \\
\text { degrade performance }\end{array}$ & \multirow[t]{2}{*}{ Sodium } & \multirow[t]{2}{*}{$32 \mathrm{mg} / \mathrm{l}$} & \multirow[t]{2}{*}{-} & $\begin{array}{l}\text { Levels above } 50 \mathrm{mg} / \mathrm{l} \\
\text { may affect } \\
\text { performance if the }\end{array}$ \\
\hline Total hardness & 60 to 180 & - & Hardness levels & & & & $\begin{array}{l}\text { sulfate or chloride } \\
\text { level is high }\end{array}$ \\
\hline \multicolumn{3}{|c|}{ Naturally occurring chemicals } & & \multirow{4}{*}{ Sulfate } & \multirow{4}{*}{$125 \mathrm{mg} / \mathrm{l}$} & \multirow{4}{*}{$250 \mathrm{mg} / \mathrm{l}$} & Higher levels have a \\
\hline Calicum & $60 \mathrm{mg} / \mathrm{l}$ & - & $\begin{array}{l}\text { Levels as low as } 14 \\
\text { mg/l may be } \\
\text { detrimental if the }\end{array}$ & & & & $\begin{array}{l}\text { laxative effect. Levels } \\
>50 \mathrm{mg} / \mathrm{may} \text { affect }\end{array}$ \\
\hline Chloride & $14 \mathrm{mg} / \mathrm{l}$ & $250 \mathrm{mg} / \mathrm{l}$ & $\begin{array}{l}\text { sodium level is higher } \\
\text { than } 50 \mathrm{mg} / \mathrm{l}\end{array}$ & & & & $\begin{array}{l}\text { performance if } \\
\text { magnesium and } \\
\text { cnloride leves are }\end{array}$ \\
\hline \multirow[t]{2}{*}{ Copper } & \multirow[t]{2}{*}{$0.072 \mathrm{mg} / \mathrm{l}$} & \multirow[t]{2}{*}{$0.6 \mathrm{mg} / \mathrm{l}$} & \multirow{2}{*}{$\begin{array}{l}\text { Higher levels produce } \\
\text { a bad odor and taste } \\
\end{array}$} & & & & high. \\
\hline & & & & Zinc & - & $1.50 \mathrm{mg} /$ & Higher levels are toxic \\
\hline
\end{tabular}

Fig 2: Drinking water quality guidelines for poultry 

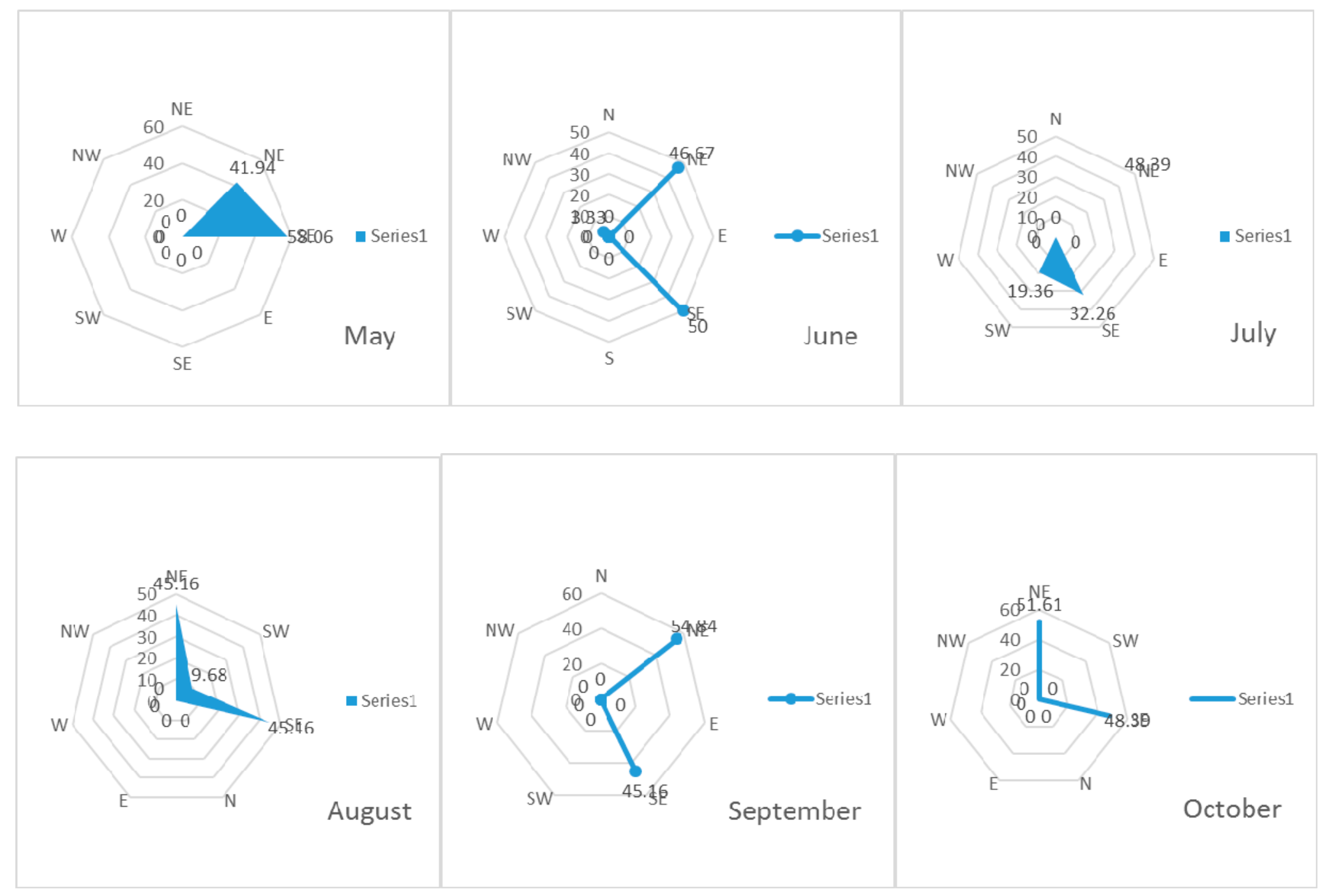

Fig 3a: Meteorological Data for the study area (Wind Direction, May-October) 


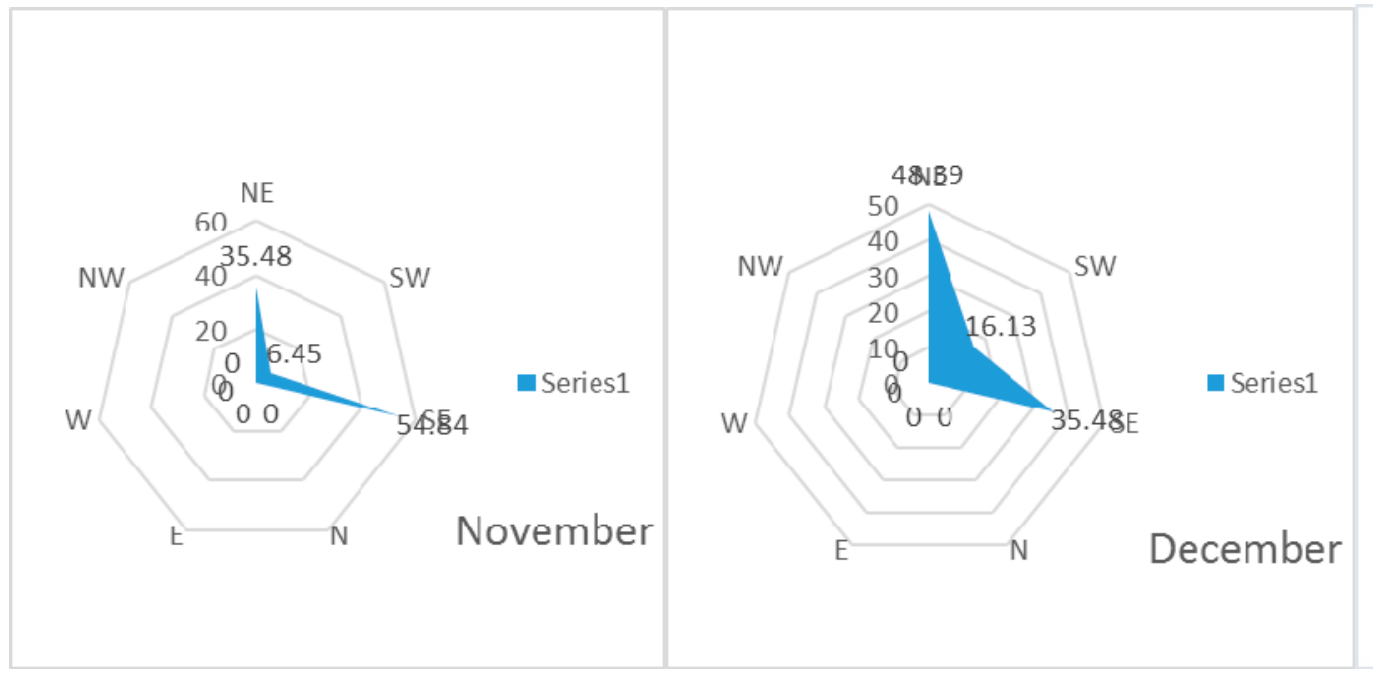

Wind Direction (November and December)

\section{Daily Data Distribution}

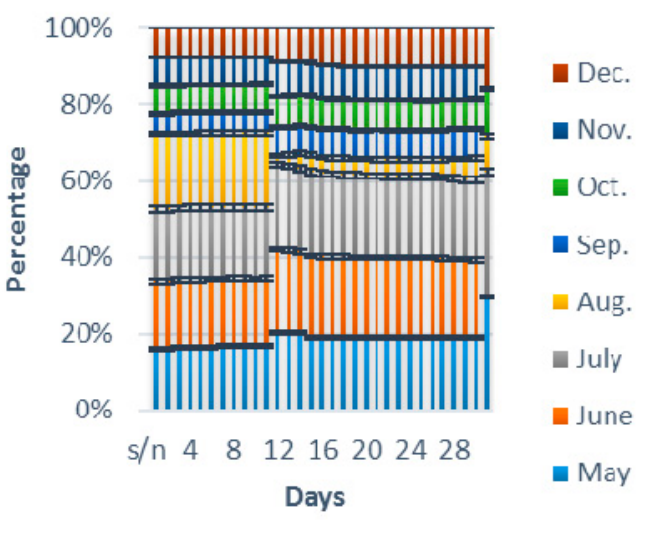

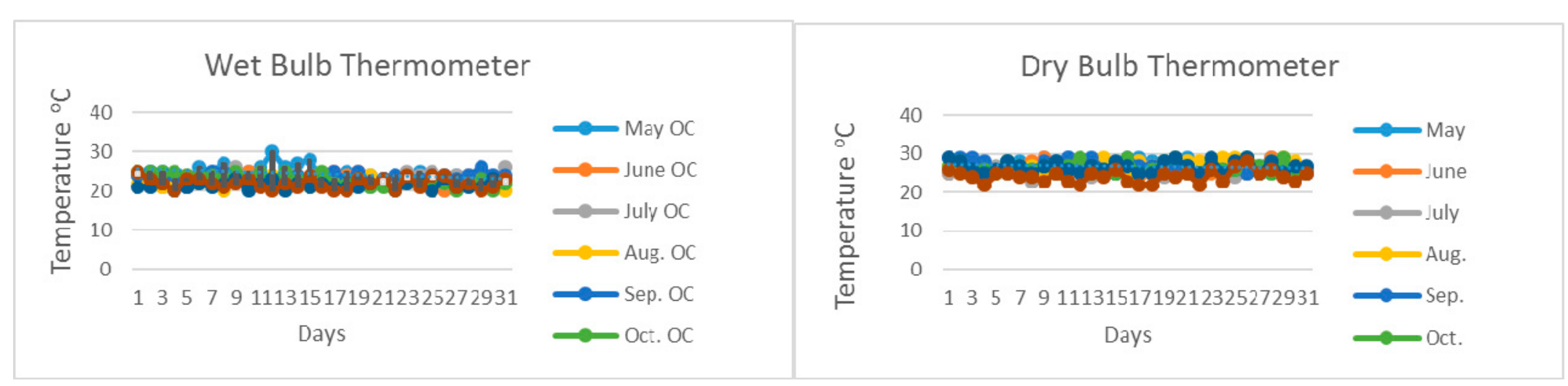

Dry and Wet Temperature $\left({ }^{\circ} \mathrm{C}\right)$ (May to December)

Fig 3b: Meteorological Data for the study area 
Table 1: Descriptive Statistics of Physico-Chemical Properties of Rainwater Samples

\begin{tabular}{|c|c|c|c|c|c|c|c|c|c|c|}
\hline Parameters & $\begin{array}{l}\text { TDS } \\
(\mathrm{mg} / \mathrm{L})\end{array}$ & $\begin{array}{l}\text { Temp } \\
\left({ }^{\circ} \mathrm{C}\right)\end{array}$ & $\mathrm{pH}$ & $\begin{array}{l}\mathrm{EC} \\
(\mu \mathrm{S} / \mathrm{cm})\end{array}$ & $\begin{array}{l}\text { Free } \mathrm{CO}_{2} \\
(\mathrm{mg} / \mathrm{L})\end{array}$ & $\begin{array}{l}\text { Nitrate } \\
(\mathrm{mg} / \mathrm{L})\end{array}$ & $\begin{array}{l}\text { Phosphate } \\
(\mathrm{mg} / \mathrm{L})\end{array}$ & $\begin{array}{l}\text { Sulphate } \\
(\mathrm{mg} / \mathrm{L})\end{array}$ & Colour & Odour \\
\hline May & 6.00 & 27.00 & 6.2 & 8.00 & 27.00 & 0.07 & 0.13 & 0.15 & Colourless & Objectionable \\
\hline June & 7.00 & 27.00 & 6.5 & 14.00 & 26.00 & 0.83 & 0.17 & 0.15 & Colourless & Objectionable \\
\hline July & 8.00 & 27.00 & 6.2 & 16.00 & 24.00 & 0.09 & 0.15 & 0.17 & Colourless & Objectionable \\
\hline August & 8.00 & 27.00 & 6.3 & 17.00 & 32.00 & 0.60 & 0.16 & 0.18 & Colourless & Objectionable \\
\hline September & 4.00 & 28.00 & 6.1 & 8.00 & 28.00 & 0.05 & 0.17 & 0.18 & Colourless & Objectionable \\
\hline October & 4.00 & 28.00 & 6.9 & 9.00 & 16.00 & 0.05 & 0.17 & 0.18 & Colourless & Objectionable \\
\hline November & 19.00 & 31.00 & 7.6 & 38.00 & 24.00 & 0.05 & 0.18 & 0.22 & Colourless & Objectionable \\
\hline December & 42.00 & 30.00 & 7.2 & 84.00 & 18.00 & 0.05 & 0.18 & 0.24 & Colourless & Objectionable \\
\hline Minimum & 4.00 & 27.00 & 6.10 & 8.00 & 16.00 & 0.05 & 0.13 & 0.15 & - & - \\
\hline Maximum & 42.00 & 31.00 & 7.60 & 84.00 & 32.00 & 0.83 & 0.19 & 0.24 & - & - \\
\hline Mean & 12.25 & 28.13 & 6.63 & 24.25 & 24.38 & 0.16 & 0.17 & 0.18 & - & - \\
\hline Standard Dev & 12.93 & 1.53 & 0.56 & 26.04 & 5.24 & 0.27 & 0.02 & 0.03 & - & - \\
\hline Coff. Variation (\%) & 105.52 & 5.52 & 8.30 & 107.37 & 21.48 & 176.25 & 11.22 & 17.19 & - & - \\
\hline Skewness & 2.20 & 1.25 & 0.95 & 2.18 & -0.44 & 2.81 & -0.81 & 0.88 & - & - \\
\hline Kurtosis & 4.90 & 0.24 & -0.50 & 4.79 & -0.26 & 7.92 & 0.92 & 0.04 & - & - \\
\hline
\end{tabular}


Table 2: Correlation Matrix of the Physico-chemical Parameters

\begin{tabular}{|c|c|c|c|c|c|c|c|c|}
\hline Parameters & TDS & Temp & $\mathrm{pH}$ & $\mathrm{EC}$ & Free $\mathrm{CO}_{2}$ & Nitrate & Phosphate & Sulphate \\
\hline TDS & 1 & & & & & & & \\
\hline Temp & 0.710 & 1 & & & & & & \\
\hline $\mathrm{pH}$ & 0.648 & 0.900 & 1 & & & & & \\
\hline $\mathrm{EC}$ & 0.998 & 0.716 & 0.660 & 1 & & & & \\
\hline Free $\mathrm{CO}_{2}$ & -0.441 & -0.446 & -0.589 & -0.449 & 1 & & & \\
\hline Nitrate & -0.182 & -0.329 & -0.128 & -1.178 & 0.144 & 1 & & \\
\hline Phosphate & 0.621 & 0.721 & 0.702 & 0.658 & -0.449 & 0.066 & 1 & \\
\hline Sulphate & 0.854 & 0.892 & 0.775 & 0.870 & -0.450 & -0.462 & 0.769 & 1 \\
\hline
\end{tabular}




\section{REFERENCES}

Elsaidy N, Mohamed RA, Abouelenien F (2015). Assessment of variable drinking water sources used in Egypt on broiler health and welfare, Veterinary World 8(7): 855-864.

Jacquie Jacob (2015). Water Requirements of Poultry. eXtension.org

Kentucky Poultry Energy Efficiency Project (2014). WATER QUALITY. Production manual. University of Kentucky, College of Agriculture. Chapter 12.

Donald L. Pfost, Charles D. Fulhage and Stan Casteel (2001).Water Quality for Livestock Drinking. EQ381, Water Quality for Livestock Drinking. University of Missouri Extension.

Lazarus Leonhard (Accessed 2016). Salinity - what do those figures mean? Apps Laboratories.com

Carles, S., Groulx, D.B., Lamhamedi, M.S., Rainville, A., Beaulieu, J., Bernier, P., Bousquet, J., Deblois, J. and Margolis, H.A. 2015. Family variation in the morphology and physiology of white spruce (Picea glauca) seedlings in response to elevated $\mathrm{CO}_{2}$ and temperature. Journal of Sustainable Forestry 34: 169-198.

Olowoyo, D. N. (2011). Physicochemical characteristics of rainwater quality of Warri axis of Delta State in western Niger Delta region of Nigeria. Journal of Environmental Chemistry and Ecotoxicology 3 (12): 320-322.

Olaoye, R.A, Olaniyan,O.S (2012). Quality of Rainwater from Different Roof Material. International Journal of Engineering and Technology. 2 (8): 1413-1421. 
Abulude F.O and Akinnusotu A (2016). Source Characterization of Metals in Rainwater: Case Study of Akure, Ondo State, Nigeria. International Journal of Environment and Bioenergy. In Press

TNAU Agritech Portal (2016). Effect of wind on crop production. Agrometerology: Wind and Plant Growth. Accessed 8 $8^{\text {th }}, 2016$.

Onoda Y and Anten N.P.R (2011).Challenges to understand plant responses to wind. Plant Signaling \& Behavior 6 (7): 1057-1059.

Hoogenboom G (2000). Contribution of agrometeorology to the simulation of crop production and its applications. Agricultural and Forest Meteorology. 103: 137-157.

Haile M (2005). Weather patterns, food security and humanitarian response in sub-Saharan Africa. Phil. Trans. R. Soc. B. 360, 2169-2182. doi:10.1098/rstb.2005.1746.

Agroinfo (2015). Importance and Scope of Meteorology in Agriculture. My Agriculture Information Bank. Accessed 12 $2^{\text {th }}$ August, 2016.

(C) 2017 by the authors; licensee Preprints, Basel, Switzerland. This article is an open access article distributed under the terms and conditions of the Creative Commons by Attribution (CC-BY) license (http://creativecommons.org/licenses/by/4.0/). 